\title{
The European Union's 'Potential We' between Acceptance and Contestation: Assessing the Positioning of Six Eastern Partnership Countries*
}

ALENA VIEIRA (iD

Research Centre in Political Science (CICP) and University of Minho, Braga

\begin{abstract}
The present contribution analyses the European neighbourhood policy and the Eastern Partnership (EaP), which celebrated its tenth anniversary in 2019, from the perspective of social identity theory. It is argued that the evolution of both the European neighbourhood policy and the EaP corresponds to the emergence of a distinct EU identity: its 'potential we', which has been defying the Russian 'significant we' extended to the EaP states. Drawing on the framing analysis of strategic documents and statements, which identifies eight distinct themes, the contribution ascertains three different patterns of EaP states' interaction with the EU: Georgia, Moldova and Ukraine accepting the 'EU's potential we', Armenia holding to the potential we, and Azerbaijan, as well as Belarus, contesting the potential we.
\end{abstract}

Keywords: altercasting; Eastern partnership; European neighbourhood policy; Russia; social identity theory

\section{Introduction}

Since its inception in 2004 the European neighbourhood policy (ENP) has evolved dynamically. Having survived political turbulence such as the Arab Spring in 2011 and Russia's annexation of Crimea in 2014, it has been the subject of several reviews and identified as a priority for EU foreign policy to address. In 2009 it was complemented by the eastern partnership (EaP), which aimed to invigorate EU relations with neighbouring eastern states by offering an unprecedented level and breadth of association, manifested in the association agreements (AAs) and the deep and comprehensive free trade areas (DCFTAs). However, the negotiation, conclusion and implementation of the AA/DCFTAs with Ukraine, Georgia and Moldova has resulted in the coexistence of very different types and rationales of relationships with participating states under the same initiative. These include the three AA/DCFTA-oriented states mentioned above, states that have reached a special arrangement without the DCFTA (such as Armenia's comprehensive and enhanced partnership agreement [CEPA]) and other states that display no interest in deepening their contractual relationship (Azerbaijan and Belarus).

As a result, the current motley state of the EaP represents an analytical challenge that deserves exploration. The EaP celebrated its tenth anniversary in 2019 and currently

\footnotetext{
* This study was conducted at the Research Center in Political Science (CICP) (UIDB/CPO/00758/2020), University of Minho/University of Évora and supported by the Fundação para a Cência e Tecnologia (Portuguese Foundation for Science and Technology, FCT) and the Portuguese Ministry of Education and Science through national funds. The author would like to thank the anonymous reviewers and the JCMS editors for their very constructive feedback.
} 
oversees a region that has become a site of competing, if not clashing, EU and Russian socio-political order. At the same time, the EU has been enduring one of the most difficult periods in its history with a number of existential challenges, including the global economic and financial crisis, the migration crisis, Brexit and increased terrorist acts in member states, all affecting the EU's image and credibility. Despite such adverse circumstances, EaP countries have embraced the AA/DCFTA and their citizens have defended their decision to follow a pro-EU course, even, as was the case for Ukrainians in the Maidan, at the cost of their lives.

While both the ENP and the EaP have attracted broad scholarly attention, inspiring the application of diverse analytical approaches, theories and traditions (Baltag and Bosse, 2016; Bosse, 2009; Casier, 2011; Whitman and Wolff, 2010), theory-informed accounts of the policies of the six EaP participants have been rare. This article aims to fill that gap. In doing so, rather than adopting a view of individual EaP states as mere recipients of EU-promoted norms and values, this study positions itself as part of an emerging sub-stream of EaP studies that emphasizes the agency of EaP countries and pays special attention to domestic contexts (Bosse, 2010; Delcour, 2019; Vasilyan, 2016).

The present study adopts a constructivist approach that allows us to consider the meaning that EaP countries attribute to their cooperation with the EU in a particular regional context also defined by Russia (Busygina, 2017; Samokhvalov, 2017; Verpoest, 2007). This theoretical perspective informs the choice of analytical framework, which is one that combines constructivist and symbolic interactionist perspectives with social identity theory (SIT). Using this approach, three ideal types of EU-EaP interaction are developed, serving as a point of departure for applying a framing analysis to classify EaP states' positioning towards the EU (see Tables 1 and 3). This article argues that the diversity of the EaP is a result of ongoing social interaction between the EU and EaP countries, accompanied by a constant (re)articulation of their respective identities, and is informed by the positioning of EaP states towards a particular dimension of the EU's 'self': the 'potential we'.

The article is structured as follows. The next section presents the analytical framework and develops the three ideal types of EU-EaP interaction while also discussing methodological choices and data. This is followed by the presentation of a distinct perspective on the emergence and evolution of the ENP/EaP as the EU's potential we, and a subsequent exploration of the positioning of the six EaP states, in which eight distinct themes were identified: civilizational choice, complementarity, conditionality, democracy, irreversibility, reforms, pragmatism and strategic partnership (see Table 2). The article

Table 1: Three Ideal Types of EU-EaP Interaction

\begin{tabular}{ll}
\hline $\begin{array}{c}\text { Ideal } \\
\text { type }\end{array}$ & EaP states' positioning towards the EU's potential we \\
\hline 1 & $\begin{array}{l}\text { Accepting the EU's projection of self/potential we, reverse altercasting towards Russia as the 'other' } \\
2\end{array}$ \\
Accepting of Russia's projection of self as EaP states' 'significant we', reverse altercasting towards \\
the EU as the other
\end{tabular}

Note: Eap, Eastern partnership.

C 2020 University Association for Contemporary European Studies and John Wiley \& Sons Ltd 


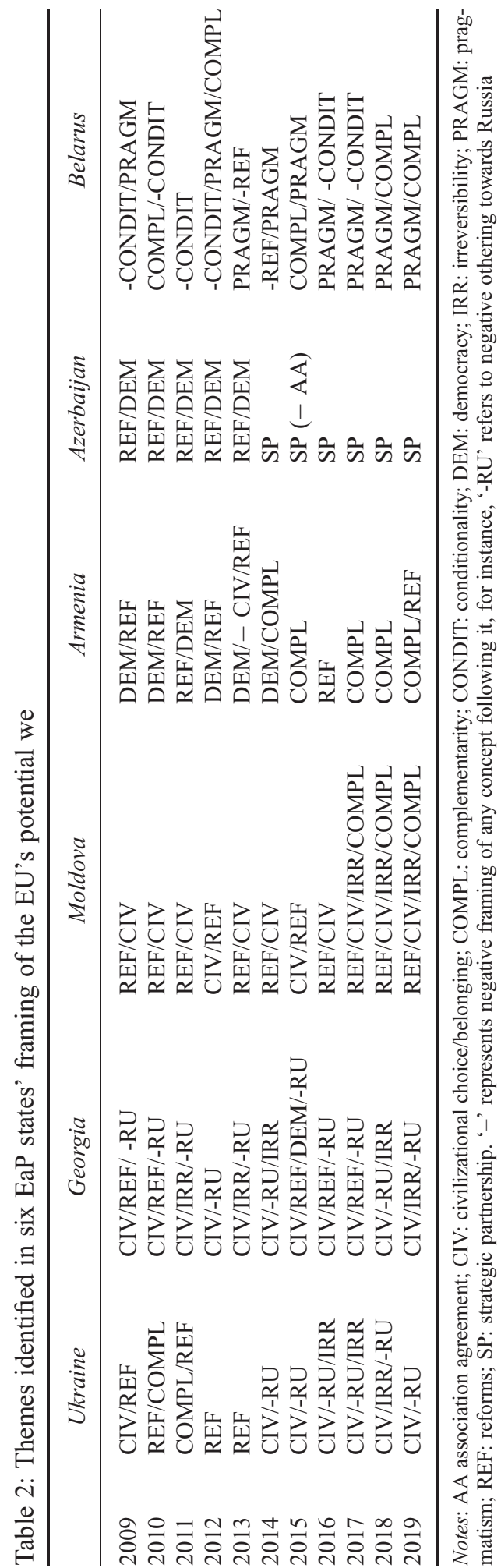


concludes with a discussion of the findings and a revised classification of EaP states' positioning (see Table 3).

\section{Exploring the Eastern Partnership: The Analytical Framework}

To lay bare the current diversity within the EaP, the analytical framework of this study combines constructivism and symbolic interactionism (Adler-Nissen, 2016; Mead, 1934) with SIT. Both are underpinned by the assumption that identity is a social construct, whereby the agent's self is conceived as complex, contingent, always in the making and in a special relationship with the other. Additionally, SIT emphasizes agents' inherent aspiration to maximize their self-esteem, which is possible only in social relationships and significant groups (Mols and Webber, 2013; Tajfel and Turner, 1986). Another characteristic of SIT is its focus on categorization processes, which are determined by the other from which an agent seeks distance, and which is furthermore defined in opposition to the self, and by a shared significant we that the self strives to become. Thus, the identities of both the EU and individual EaP states can be analysed through particular categorizations of the self as a member of a group that is different from others. Contrary to several constructivist approaches, SIT is not restricted to one particular (ego/alter) social dyad (Malici and Walker, 2014) and is therefore capable of capturing the complexity of the social space in which EaP states operate, namely the EU-Russia common neighbourhood, where belonging to competing social groups is crucially important and contested (Samokhvalov, 2017).

While adopting the postulates of SIT and its emphasis on categorization, the present contribution is interactionist in its essence: social processes of interaction are considered continuous, 'performative and mutually constitutive' (Malici and Walker, 2014). The key mechanism of identity (re)articulation is altercasting, whereby certain self-representations of one actor are projected onto another. By manipulating symbolic cues to frame how the latter actor defines social situations, whether positively or negatively, the former actor is

Table 3: EaP States' Positioning toward the EU's 'Potential We'

\begin{tabular}{|c|c|}
\hline EaP states & Positioning towards the EU's potential we altercasting \\
\hline Georgia (IT1) Ukraine (IT1) & $\begin{array}{l}\text { Accepting the EU's potential we: civilizational choice and irreversibility } \\
\text { Reverse altercasting: 'prospective we' towards the EU, 'self-other' } \\
\text { towards Russia (negative othering) }\end{array}$ \\
\hline Moldova (IT1) & $\begin{array}{l}\text { Accepting the EU's potential we: reforms, civilizational choice, } \\
\text { complementarity, irreversibility } \\
\text { Reverse altercasting: prospective we towards the EU }\end{array}$ \\
\hline Armenia & $\begin{array}{l}\text { Holding to the EU's potential we: democracy and reforms (including } \\
\text { accountability, rule of law, fight against corruption), not at the expense } \\
\text { of the acceptance of Russia's significant we, and in line with the } \\
\text { complementarity principle }\end{array}$ \\
\hline Azerbaijan (IT3) & $\begin{array}{l}\text { Contestation of the EU's potential we: strategic partnership } \\
\text { Reversed altercasting: self-other towards both Russia/EU }\end{array}$ \\
\hline Belarus & $\begin{array}{l}\text { Contestation of the EU's potential we: pragmatism } \\
\text { Acceptance of Russia's significant we }\end{array}$ \\
\hline
\end{tabular}

Note: Eap, Eastern partnership; IT, ideal type. 
eventually forced to adjust their behaviour to target the other actor's view of themselves in the given situation (Wendt, 1999). The ENP/EaP can be thus seen as a case of the EU altercasting or projecting a particular identity of the self onto its EaP partners. The latter can accept or reject this identity and project their own alternative self onto the EU, in what is referred to here as 'reversed altercasting'.

The following analysis of EU-EaP interaction is informed by three ideal types that represent a 'synthesis of many diffuse, discrete [...] individual phenomena, arranged according to those one-sidedly emphasized viewpoints into a unified thought construct' (Weber, 1949). The first ideal type rests upon the successful projection of an accepted EU identity/self onto EaP states. The legitimacy of certain political changes and choices, be they related to democratization, the promotion of the rule of law, good governance and reforms in general, derives from a specific discursive representation wherein the identities of EaP states are associated with the self the EU projects onto them (the potential we). This implies a rejection of Russia's significant we and reverse altercasting of Russia as the other of these EaP states. The second ideal type is a mirror image of the first; the EaP states accept Russia's altercasting as their significant we, using their association with Russia to legitimate their domestic and foreign policies while rejecting the EU's potential we and projecting reversed altercasting towards the EU to establish self-other interaction. Finally, a third ideal type can be distinguished, where neither the EU nor Russia's projection of self is accepted and domestic and foreign policies are independent from the projected identities of Russia and the EU (Table 1).

To uncover how the six states define themselves in relation to the EU's potential we, this article employs a framing analysis. Rein and Schön (1993, p. 146) describe framing as 'a way of selecting, organizing, interpreting, and making sense of a complex reality to provide guideposts for knowing, analyzing, persuading, and acting'. Frames result from actors' need to reduce complexity while conveying their discourses, acting as 'interpretative packages' (Gamson and Modigliani, 1989, p. 3) that give meaning to an issue by defining problems, diagnosing causes, making moral judgments, and suggesting remedies (Entman, 1993, p. 52). The framing approach chosen here (Rein and Schön, 1993; van Hulst and Yanow, 2016) abstains from predefined frames, allowing these to emerge from the text. The goal of this analysis is to identify existing frames by establishing when and how statements invoking the terms integration, European/Eurasian, agreement (AA/DCFTA), and Russia have been used. By drawing on the three ideal types defined in Table 1, however, some expectations about the EaP's framing and the associated processes of naming, selecting and storytelling can be advanced (Rein and Schön, 1993).

Countries of the first type are expected to adopt the framing that prioritizes the AA/DCFTA, unlike states that ignore it or frame it as a second-order issue. Their framing of both the AA/DCFTA and the Russia-Eurasian Economic Union (EAEU) is expected to carry an inherent (rather than neutral) valence, that is, a directional bias emphasizing positive or negative aspects of certain issues or events (De Vreese and Boomgaarden, 2003), expressed in salient analogies and metaphors. Increased cooperation and integration with the EU is expected to be invoked by a particular storyline to further this end, as a foundation for respective altercasting. Conversely, countries of the second ideal type are expected to prioritize Russia and the EAEU, corresponding to EaP states' acceptance of these as their significant we, while casting AA/DCFTA integration and the EU in terms of 'otherness', a process accompanied by salient metaphors and constitutive framing. 
Further integration with Russia and within the EAEU is predicted to be framed as a necessary or even the right thing to do, expressed in the respective reversed altercasting. Finally, countries of the third ideal type are expected to abstain from referring to integration with either the EU or Russia and the EAEU as a guideline for their development, developing alternative storylines.

To identify frames that unveil the (differential) narratives underlying EaP states' positioning towards the EU's potential we between 2009 and 2019, strategic documents from the six EaP states were examined, namely, their national security strategies (NSS), national military strategies (NMS), national military concepts (NMC) and military doctrines (MD). In addition to these 18 documents, 86 key statements (annual addresses, inauguration speeches, messages to Parliament and statements at international conferences and summits including (United Nations General Assembly sessions and the Munich security conference) given by EaP state officials with the authority to articulate the choices of their respective countries are analysed, considering one statement per country per year from 2009 to 2019 (see Supplementary Information document). ${ }^{1}$ The statements were collected from publicly available sources, such as official EaP state institutions websites and the Wayback Machine digital archive. Official English translations of the documents and statements were, whenever possible, compared with the originals to verify the accuracy of the translations from Russian, Ukrainian and Belarusian. Triangulation of the collected data was supported by an analysis of academic publications and newspaper articles in addition to fieldwork carried out by the author in Kiyv (in May 2013), Minsk (July 2017) and Brussels (May 2019).

\section{The ENP and the EaP: Emergence and Consolidation of the EU's Potential We}

The origins of the ENP/EaP trace back to the end of the Cold War, which can be considered a social encounter (Wendt, 1999, p. 267) between the EC/EU and the eastern states. Faced with the need to define a new relationship with the latter, the EC/EU revised its long-standing idea of itself as a dynamic economic community of states committed to liberal values, defined in opposition to Europe's own warring past as an ideational other (Flockhart, 2011; Waever, 1998). Following the Treaty of Maastricht the subsequent consolidation of the EU as an international actor throughout the 1990s was intertwined with the EU's eastern enlargement. The latter entailed a large-scale socialization process to bring central and eastern European countries (CEES) into the liberal institutional order - underpinned by norms and values such as democracy, the market economy, and the rule of law - and can be considered successful EU-CEES altercasting. A new facet of the EU's self as a socializer (Noutcheva, 2017) and significant we to others was defined, accompanied by the categorization of eastern states that separated the CEES and the Baltic states from the commonwealth of independent states. While the former established a closer association with the EU's 'we', expressed in the CEES' candidate status that corresponded to the EU's prospective we (Flockhart, 2011), the EU has also been projecting a 'generalized we' towards commonwealth of independent states countries, an identity in which the EU's self continued to be a socializer and was generally accepted.

\footnotetext{
${ }^{1}$ Additional documents (statements given at the EaP conferences, bilateral meetings) were considered in cases when those named were insufficient to ascertain the framing of the EU's potential we.
} 
It was in the context of evolving eastern enlargement and growing enlargement fatigue that the EU conceived and launched the new ENP in 2004 as a 'ring of friends' and a zone of 'prosperity and a friendly neighbourhood' (European Commission, 2003). By offering a reinforced relationship and support for democratic reforms, the rule of law and a functioning market economy, the EU simultaneously forged a new identity category, the potential we, distinct from the already established prospective we corresponding to EU candidate status (Vieira, 2016). The potential we was defined as 'more than partnership' but 'less than membership' (Prodi, 2002), and its emphasis on inclusive 'we-ness' went hand in hand with reliance on the EU's enlargement operational mechanisms, including political conditionality and the acquis communautaire and the (reinforced) role of the EU as a socializer.

One of the immediate reactions to the ENP came from Russia. Although it was initially included in the initiative, Russia declared it would not join the mechanism, maintaining that its status as an EU strategic partner was incompatible with the ENP. The EU-Russia strategic partnership, underpinned by the four common spaces, has been increasingly defined by a self-other interaction (Schmidt-Felzmann, 2016) as a result of Russia's reversed altercasting aimed at revising the previous interaction pattern wherein EU-promoted norms and values, including the acquis communautaire, were generally accepted. While establishing the precedent of rejecting the EU's potential we, Russia's position also defined the EU-Russia strategic partnership as a non-ENP relationship, evolving in opposition to the ENP.

The EaP fostered the evolution of the EU's potential we, offering further political association and economic integration. Launched in 2009, the EaP reinforced sectoral reforms in target countries by 'highly targeting conditionality at a sectoral level' (Delcour and Wolczuk, 2015, p. 499) and established the prospect of an enhanced relationship with the EU, one with 'unprecedented scale and intensity of linkages' (Delcour and Wolczuk, 2015, p. 499). The AA and DCFTA were the institutional expression of this new offer and worked towards consolidating the EU's potential we. Through these mechanisms, the EU provided economic and financial assistance and access to EU programmes and agencies, and granted visa-free travel to Moldova (2014), Ukraine (2017) and Georgia (2017), while also launching pilot initiatives such as the Eastern Partnership European School in Tbilisi, inaugurated in September 2018. The special position of three AA/DCFTA states has also been reflected in their sector-specific categorization; for example, the 'DCFTA facility for small and medium enterprises' (SME) under the SME flagship initiative.

Unlike the ENP, the EaP raised concern in Moscow (Busygina, 2017). Whereas Russia regarded the ENP as an initiative with the general aspiration to socialize target states into the generalized we, replicating Russia's pattern of interaction with the EU during the 1990s, the EaP was seen as an attempt to move EaP countries away from Russia as their significant we. Russia has therefore been eager to strengthen its own integration project, the Eurasian custom (and, subsequently, economic) union (EAEU) (Smith and Richardson, 2017), while using carrots, such as loans, natural gas, and oil deals, and sticks, such as sanctions and blocking imports, tariffs and higher gas prices, to attract new members (Samokhvalov, 2017).

The extent of Russia's challenge to the autonomy of the EU's potential we became clear at the 2013 EaP Vilnius summit, with Armenia's U-turn away from the AA/DCFTA 
towards the Eurasian Customs Union, which preceded the EAEU and Ukraine's decision to suspend the AA/DCFTA, eventually paving the way for Euromaidan and armed conflict in Ukraine (Kropatcheva, 2016; Raik, 2017). Since then, Russia's annexation of Crimea in March 2014 and military actions in eastern Ukraine have presented constant challenges to the core of EU identity. This dramatically changing context has forced EaP states to actively revise their self, significant we and other, both towards Russia and the EU.

\section{Accepting the EU's Potential We: Georgia, Moldova and Ukraine}

Based on the AA/DCFTAs signed in 2014, Georgia, Moldova and Ukraine have accepted the EU's potential we and adopted a course towards comprehensive reforms, supported by centralized programming and implementation strategies, despite the difficulties inherent to the reform process like state capture, selective justice and political instability. In doing so, two of these three countries, namely Georgia and Ukraine, have displayed what can be termed 'civilizational' ${ }^{2}$ framing. Their strategic documents and discourses frame the AA/DCFTA as a matter of civilizational belonging and civilizational choice (Bakhtadze, 2018, SI 2.4; Bakhtadze, 2019, SI 2.2; Poroshenko, 2017, SI 1.4) associated with the idea of a 'return to Europe' (Yushchenko, 2009a, SI 1.18). The AA/DFCTA framing also demonstrates a tendency towards constitutive concepts and metaphors, such as a 'master plan for Europeanisation and true modernisation' (Garibashvili, 2014, SI 2.10) and a means to achieve ‘deep internal Europeanisation' (Poroshenko, 2018, SI 1.3). In addition to specific reform achievements and prospects, ${ }^{3}$ European values (democracy, the rule of law and good governance) accompany references to the AA/DCFTA. These are phrased in existential terms as something safeguarding a particular political course, whereby the promotion of democracy and the reform process is intertwined with the country's security and independence and, as a result, the very existence of Ukraine and Georgia as states (Poroshenko, 2015, SI 1.8; Poroshenko, 2017, SI 1.4), and a 'guarantee for maintaining our self-cognition' (Margvelashvili, 2014, SI 2.9). This ontological security framing of AA/DCFTA also concerns the separation of both Ukraine and Georgia from their Soviet past, thereby reinforcing the 'othering' of Russia (Delcour, 2019) ${ }^{4}$ and bringing the theme of irreversibility to the forefront. Table 2 summarizes the framing analysis of Georgia and Ukraine as well as other EaP countries.

In Ukraine and Georgia the EAEU is mostly ignored; when mentioned, it is framed as analogous to the Soviet Union in terms that evoke the opposite of 'positive feelings and self-esteem from the alternative group membership' (Mols and Webber, 2013, p. 512): 'in essence, nothing other than the Soviet Union on behalf of the Russian Federation' (Yatsenyuk, 2014, SI 1.10), or 'a new form of the Soviet Union initiated by Putin to undermine the progress achieved in our region with respect to NATO and the EU' (Saakashvili cited in civil.ge, 2013; see Saakashvili, 2013, SI 2.11).

\footnotetext{
${ }^{2}$ In the present analysis, the term 'civilizational' refers to the political (not cultural and historical) dimensions of EaP states' identities.

${ }^{3}$ This is despite Georgia's initial resistance to some of the EU-promoted reforms prior to 2008 (Delcour, 2019).

${ }^{4}$ Russia is defined as an occupying power in Georgia's NMS (2014, SI 2.8) and as an occupying power and aggressor in Ukraine's MD (2015, SI 1.6). While the West is criticized in both countries for its appeasement of Russia, there are significant differences in dealing with the latter, as can be seen by comparing President Saakashvili's intense negative othering approach with his successors' pragmatism and 'strategic patience' (Margvelashvili, 2018, SI 2.3).
} 
Ukraine and Georgia have firmly nested their AA/DCFTA framing in the prospective we, corresponding with the EU membership perspective. The latter has been framed as a strategic foreign policy objective in key national strategy documents (Georiga's NSC, 2011, SI 2.13; Georgia's NMS, 2014, SI 2.8; Ukraine's NSS, 2007, SI 1.20; Ukraine's NSS, 2012, SI 1.14; Ukraine's NSS, 2015, SI 1.7). Moreover, both states have enshrined their commitment in constitutional amendments approved by the Parliament of Georgia in 2017 and by Ukraine's Verkhovna Rada in February 2017 (Constitutional Law of Georgia, 2017; Law of Ukraine 2,680-VII, 2019). These EaP states have also been eager to project their own reversed altercasting onto the EU to reaffirm their importance as an internal part of the European order (Kvirikashvili, 2017, SI 2.5), be it by contributing to common security and defence policy missions, or by advancing reforms in the framework of the energy community. They have specifically targeted the EU's prospective we, as reflected in the idea of 'four unions with the EU (customs union, energy union, digital single market, Schengen area)' promoted by President Poroshenko, in Ukraine's vehement rejection of the associated status proposal (UNIAN, 2019), or in President Salome Zurabishvili's aspiration to find 'outside the box' solutions (Zurabishvili, 2019, SI 2.1) such as 'accession negotiations on an ad hoc basis' (cited in Euractiv, 2019). However, EU officials have rejected EaP states' reversed altercasting, insisting on a strict separation of EU-EaP relations from the EU's prospective we.

While Moldova is similar to Ukraine and Georgia, its cooperation with the EU has been complicated by especially acute internal polarization and the parallel process of state capture. The competition between the EU and Russia for the role of Moldova's significant we has led reforms (especially associated with economic modernization) to become a dominant theme in its acceptance of the EU's potential we. The AA/DCFTA is accordingly viewed as 'the best and most viable option to deliver prosperity and sustainable development' (Filip, 2018, SI 3.4) and to establish 'civilized standards of living' (Filip, 2016a, SI 3.7), in addition to 'strengthening security' (NSS, 2008, SI 3.20; NSS, 2011, SI 3.16). This is in spite of the fact that Moldova's AA/DCFTA framing remains nested within the prospective we, corresponding to aspirations to EU membership, as a 'step on the way to getting the "European passport"' (Filip, 2016b, SI 3.8) and a "bridge to be crossed' to enter the EU (Timofti, 2013, SI 3.13). The centrality of reform is intertwined with Moldova's credibility and the precedent set when the EU provided almost unconditional support to the 'pro-European' leadership of the country, which was later associated with state capture and the notorious bank fraud exposed in 2014. This record affected Moldova's reverse altercasting towards the EU's prospective we by making it generally less assertive in expressing its EU membership aspirations than Ukraine or Georgia (also prior to 2014, cf. the metaphor of Moldova as 'not Europe's Cinderella' [Filat, cited in Moldavskie Vedomosti, 2013]).

Though credited with exerting a destabilizing influence that includes 'economic and military pressure, propaganda, misinformation and even political bribery' (NDS, 2018, SI 3.3), Russia has not been defined as a threat or occupier. 'Close cooperation' (NSS, 2011, SI 3.16) and 'dialogue' (NDS, 2018, SI 3.3) are the themes that characterize the relationship with Russia, with complementarity emerging as an important theme and also

${ }^{5}$ Russia's military presence in Transnistria, along with Transnistria's own forces, is identified as a 'threat' (NDS, 2018, SI 3.3). 
present in pre-2014 Ukraine (Yanukovich, 2010, SI 1.17; Yanukovich, 2011, SI 1.16). EU integration is repeatedly portrayed as 'not being directed against Russia' (Dodon, 2019, SI 3.1; Timofti, 2014, SI 3.11) and as compatible with close cooperation with Russia and the EAEU, as reflected by Moldova's observer status in the EAEU (requested by President Igor Dodon) since May 2018.

Moldova's framing corresponds to the first ideal type due to the predominance of the irreversibility theme, which is crucial to the civilizational framing of the other two DCFTA countries as well. The irreversibility theme concerns both the impossibility of revoking AA/DCFTA and the need to credit AA/DCFTA achievements for Moldova's growing standard of living (Filip, 2018, SI 3.4; Sandu, 2019, SI 3.2). Irreversibility was also part of Maia Sandu's reverse altercasting towards the EU, appealing to the latter to acknowledge and protect Moldova's pro-AA/DCFTA choice and portraying it as a move away from the grey zone controlled by Russia (cited in AGERPRES, 2019). The irreversibility theme has been increasingly accepted even by such critically minded actors as President Igor Dodon, who previously framed the AA/DCFTA as 'economic suicide', 'premature' and potentially revocable in a national referendum (cited in Moldavskie Vedomosti, 2016).

\section{Holding to the EU's Potential We: Armenia}

Having initially assumed a course in the direction of the AA/DCFTA and negotiating with the EU at an advanced level by 2013, Armenia seemed to have accepted the EU's potential we. This is aligned with its consistent adherence to the 'European system of values' in official statements (Sargsyan, 2009, SI 4.15; Sargsyan, 2011, SI 4.13; Sargsyan, 2013a, SI 4.10) and its aspiration to 'consolidate democracy, strengthen the rule of law, and protect human rights and fundamental freedoms' (NSS, 2007, SI 4.16). Armenia has also made tangible progress in its EU-promoted reforms (Delcour and Wolczuk, 2015, p. 492) and supported the ENP's 'more for more principle' (Sargsyan, 2011, SI 4.13). Armenia's adherence to the EU's potential we has, however, been evolving within a unique context. In the specific constellation of Armenia's identity, the valence of the other is occupied by Azerbaijan and Turkey (Oskanian, 2013), which has forced Armenia define Russia, to at least partly, as their significant we, expressed in a formal military alliance and strategic partnership (MD, 2007, SI 4.17), as well as Armenia's participation in the Russia-led collective security treaty organization (CSTO). The EU's potential we is therefore accepted in line with the 'policy of complementarity' (NSS, 2007, SI 4.16) and informed by the country's 'deep security consciousness' (Ministry for Foreign Affairs of Armenia, 2019).

While democracy and reforms emerge as dominant themes in Armenia's framing, they correspond to a broader set of values. Armenia declared that its adherence to the 'European choice' as a 'conscious course', and the 'persistent adaptation of European standards into all areas of our political, social and economic lives' (Sargsyan, 2010, SI 4.14) is informed by its aspiration to 'become a modern nation', which 'simply cannot be poor or backward' (Sargsyan, 2012, SI 4.12). Armenia therefore defends the irreversibility of state-building according to the European model (Sargsyan, 2013a, SI 4.10), which encompasses 'pure and simple concepts: liberty, democracy, a rule-of-law state, civil society', all of which 'Armenia preach[es] to its multinational citizens after having delivered itself from the clutches of all types of tyrannies, caliphates and empires' 
(Sargsyan, 2009, SI 4.15). Thus, while recognizing that 'the issue of becoming a full member of the European Union is not yet on our foreign policy agenda' (Sargsyan, 2010, SI 4.14), Armenia considers it crucial to implement European rules of the game and European standards 'not in order for others to come and assess us negatively or positively', (Sargsyan 2014 SI 4.9), but rather because 'democratic consolidation is the only way for Armenia to develop' (Sargsyan, 2014, SI 4.9), to 'make considerable progress, to change [the] lives of our citizens and to build up the organizational strength of our society' (Sargsyan, 2010, SI 4.14).

Armenian officials nevertheless abstain from subscribing to the narrative of civilizational choice towards the EU, maintaining that they are not prepared 'to view that matter in this dimension' (Sargsyan, 2013b, SI 4.11) or 'build its relations with any country at the expense of another' (Ministry for Foreign Affairs of Armenia, 2019). Instead, Armenia aspires to continue to develop parallel 'relationships and interests with our key partners' (Sargsyan, 2013b, SI 4.11). This complementarity framing correlates with Russia's concern about the weakening of its significant we towards Armenia, made manifest in Russia's open disagreement with Armenia's course towards AA/DCFTA and eventually resorting to alliance coercion and offers of financial and energy cooperation to secure Armenia's participation in the EAEU (Vasilyan, 2016). The signing of the CEPA in 2017 has reinforced complementarity as the central theme in Armenia's framing, underpinned by the idea that 'it is possible to accommodate both Armenia's membership in the Eurasian Economic Union, with all the commitments stemming thereof, and the European Union's deep and comprehensive agenda' (Sargsyan, 2015, SI 4.8). References to 'the EU/European' in Armenia's strategic discourse have been carefully balanced with the same number of references to 'Russia/the EAEU', especially after 2014 (Pashinyan, 2018 SI 4.4; Pashinyan, 2019a SI 4.1; Sargsyan, 2017, SI 4.5; Sargsyan, 2018, SI 4.3), and Armenia has expressed a desire to "explore the "compatible middle ground" (Sargsyan, 2015, SI 4.8) between the EU and the EAEU. Democracy, human rights, political freedoms, the rule of law and, more recently, accountability, the fight again corruption and judicial independence maintain their crucial role in Armenia's framing and are reinforced by the Velvet Revolution's reaffirmation of these norms and changes as irreversible (Pashinyan, 2019 SI 4.2), although increasingly decoupled from references to the EU or the European system of values (Pashinyan, 2019a SI 4.1; Sargsyan, 2016a, SI 4.6).

\section{Contesting the EU's 'Potential We': Azerbaijan and Belarus}

Although both are participants in the EaP, neither Azerbaijan nor Belarus has accepted the EU's potential we or demonstrated an interest in the AA/DCFTA: the EU is not seen as capable of altercasting either of these states as EU socializees, while the EU's political conditionality is perceived as interference in domestic affairs, regardless of both states' compliance with some degree of EU sector-specific conditionality (Ghazaryan, 2014). Both Belarus and Azerbaijan thus view their relations with the EU in terms of self-other interaction, even if the latter is the result of two different trajectories, with Russia assuming a different role in the identity of each.

Azerbaijan initially enjoyed a close relationship with the EU through the Partnership and Cooperation Agreement (PCA). Accordingly, the NSC (2007, SI 5.14) refers to the 'integration into European and Euro-Atlantic political, security, economic and other 
institutions' as a 'strategic goal' of the country, while the 2006 ENP action plan indicates that the EU 'took note' of 'Azerbaijan's expressed European aspirations' (EU-Azerbaijan Cooperation Council, 2006). Azerbaijan also seemed to have accepted the EU's potential we altercasting, as expressed in a 'strong desire to establish a new relationship based on the association agreement' (Aliyev and Van Rompuy, 2013, SI 5.8) that would also 'allow us to be closer to Europe' (press statements of President Aliyev and Van Rompuy, 2011, SI 5.10) and 'apply Europe's positive experience' (Aliyev and Van Rompuy, 2012, SI 5.9). Azerbaijan's assurances that 'the closer we are to Europe, the more opportunities we will have for development, for democratic development' (Aliyev and Van Rompuy 2013, SI 5.8) have been supported by their alignment with the CFSP declarations (since 2007) and the mobility partnership (2013), and reinforced by the strategic energy partnership (2006). Furthermore, close EU-Azerbaijan cooperation has evolved alongside Azerbaijan's reluctance to consider Russia as its significant we. The NSC (2007, SI 5.14) states that 'Azerbaijan engages in a strategic partnership and cooperation with the Russian Federation' and the former has abstained from the Russia-led EAEU and CSTO while being part (and a founding member) of the Organization for Democracy and Economic Development-GUAM.

However, the EU's potential we has been increasingly contested in Azerbaijan as the country has developed its own reversed altercasting aimed at a self-other interaction with the EU. By 2010 the lack of centralized programming and the overall selective approach to the implementation of EU-promoted requirements and norms (Ghazaryan, 2014) led to a stalemate in EU-Azerbaijan relations. The EU's critical statements on Azerbaijan's domestic politics (human rights violations, including crackdowns on political prisoners, journalists and the lesbian, gay, bisexual, transgender, intersex and queer community) were met with resentment, and one European Parliament resolution in 2015 was followed by Azerbaijan's withdrawal from the Euronest Parliamentary Assembly, the suspension of their participation in the EU-Azerbaijan Parliamentary Cooperation Committee and the questioning of their participation in the EaP overall (van Gils, 2018). In 2013, projecting its reversed altercasting towards the EU, Azerbaijan asked to substitute the AA, which had been under negotiation since 2010, with a (lighter) strategic partnership for modernization, mirroring a similar EU-Russia cooperation format. Despite having initially rejected the request, the EU reconsidered its position by 2016, following another escalation of both the Nagorno-Karabakh conflict and tensions between Russia and Turkey. Negotiations for a new agreement began in February 2017.

Azerbaijan's framing of the AA/DCFTA changed radically to reflect these changes. The country now considers the AA/DCFTA to be an unacceptable agreement that 'simply offered a mechanism that did not look like bilateral but rather like unilateral cooperation' and that 'was like a list of instructions to us' (Aliyev, 2015, SI 5.6). Moreover, this perspective of the AA/DCFTA has raised the crucial question of whether the EU would consider Azerbaijan 'a secondary member, an associate member or just an appendage' (Aliyev, 2015, SI 5.6), especially considering that, against a backdrop of 'deep economic' and 'spiritual' crisis in Europe, the very idea of Azerbaijan's 'integration' with the EU required revision (Aliyev, 2015, SI 5.6). What needed to be identified was 'a new mechanism, a new format and concept of cooperation', one capable of reflecting equality 
(Aliyev, 2015, SI 5.6) and the special status of Azerbaijan as a country of strategic importance, which the EaP had been unable to provide (Aliyev, 2017, SI 5.4). ${ }^{6}$

Azerbaijan's strategic partnership framing has evolved from a strict separation between cooperation, which is preferred, and integration, which Azerbaijan is strongly determined to avoid (Aliyev, 2016, SI 5.5). As 'not only was Azerbaijan seeking to deepen cooperation with the EU, but also the EU was seeking cooperation with Azerbaijan' (Aliyev, 2016, SI 5.5), 'common interests and mutual respect' rather than political conditionality should guide the bilateral interaction. Azerbaijan places particular emphasis on its strategic partnership agreements with nine individual EU member states, corresponding to 'a third of the European Union' (Aliyev, 2016, SI 5.5), and frames this as a tangible and positive result outweighing its disagreement with the Commission and its criticism of the European Parliament. Azerbaijan's framing also emphasizes the country's role as a site of multiculturalism, which contrasts with the troubling instances of Islamophobia seen in EU countries (Aliyev, 2016, SI 5.5). Furthermore, any consideration of EU-Azerbaijan relations must acknowledge the 'Azerbaijani contribution to EU energy security' and the 'historic' southern gas corridor (Aliyev, 2018b, SI 5.3), which has allowed Azerbaijan to 'practically redraw the energy map of Eurasia' (Aliyev, 2018b, SI 5.3). All this reinforces the idea of Azerbaijan's special status that is incompatible with accepting the EU's potential we.

As for EU-Belarus relations, these acquired features of negative othering early on, reflected in sanctions, suspended political dialogue and the absence of a contractual foundation for the relationship, the PCA. Russia has been accepted as Belarus's significant we, expressed in the bilateral integration framework of the Russia-Belarus Union State (MD, 2016, SI 6.5), 'all-encompassing cooperation' (NSC, 2010, SI 6.13), a formal military alliance and Belarus's support for all Russia-led initiatives, including the CSTO and ECU/EAEU. However, the rapprochement beginning in the mid-2000s and Belarus's participation in the EaP, albeit limited to the multilateral track, resulted in a mutual 'positive othering'. This was reaffirmed by the 2015 decision of Belarusian authorities to release political prisoners, thus allowing the EU to lift most of its sanctions, and also endorsed by Belarus's policy towards Ukraine after 2014 and its hosting of the Minsk talks. These events have occurred despite the fact that Belarus's framing continuously demonstrated the undisputed strategic priority of Russia and the EAEU ('we do not have and we cannot have a choice here' (Lukashenka, 2013, SI 6.10); Russians and Belarusians are 'one people' - 'odin narod' [Lukashenka, 2010, SI 6.14]). Any strategic ambiguity and balancing between the EU and Russia, 'as was once done in Ukraine' (Lukashenka 2010, SI 6.14), has been portrayed as leading to extremely dangerous results, which neither the EU nor Belarus could afford.

While clearly setting itself apart from the AA/DCFTA states (Deputy Foreign Minister Oleg Kravchenko, cited in Belta, 2017) and rejecting comprehensive reforms as something ill-timed and contradictory to national interests (Lukashenka, 2017a, SI 6.3), Belarus has adopted a pragmatism framing towards the EU and expresses a preference for selective engagement and project-based sectoral cooperation. This pragmatism, associated with the theme of equality-based cooperation (Lukashenka, 2012, SI 6.11), aims to

\footnotetext{
${ }^{6}$ This includes the partnership priorities agreed by the parties in July 2018 .
} 
support a relationship envisaged as an 'active dialogue on a spectrum of matters of common interest' (NSC, 2010, SI 6.13).

A central element of Belarus's framing is the rejection of EU political conditionality, portrayed as irresponsible and a source of instability, once again using Ukraine as an analogy: 'Don't you see what your policy towards Ukraine led to, and how it started?' (Lukashenka, 2017a, SI 6.3). The EU's credibility as a democratizer or promoter of human rights is viewed as being undermined by the migration crisis, leading President Lukashenka to ask, rhetorically, 'Where is your so-called democracy and tolerance? How are you treating those migrants, those children dying in the Mediterranean Sea?' (Lukashenka, 2017a, SI 6.3). This is in addition to the EU's perceived incoherence, related to their expectation that Belarus accept 160,000 Ukrainian migrants at a time when Poland had difficulty 'digesting' 5,000 of them (Lukashenka, 2017a, SI 6.3). In this regard, Belarus appears to be the 'most secure' transit territory within the wide area stretching over $1,000 \mathrm{~km}$ that connects the EU to Russia and China (Lukashenka, 2017a SI 6.3). Likewise, the EU is expected to accept Belarus's pragmatic positioning, abandon conditionality-based engagement ('Europeans must come to their senses'), and engage in dialogue to 'work together for the stabilization of Europe' (Lukashenka, 2017a, SI 6.3). A distinct complementarity storyline emerges on the EaP, first and foremost as a platform for cooperation (which could include intertwining the EaP and the EAEU in the future [Lukashenka, 2015, SI 6.6]) oriented towards avoiding any lines of division, rather than forcing participating countries to choose between East and West.

Belarus's abstention from any negative othering altercasting towards the EU, or from reasserting the autonomy of its self towards the latter, has been closely associated with the importance attributed to closer EU cooperation as a means to mitigate the excessively pro-Russian orientation that existed prior, referred to as 'flying with one wing' (Lukashenka, 2017b, SI 6.4). Belarus considers the EU crucial to supporting their sovereignty and independence vis-à-vis Russia, which became an especially controversial matter in light of Russia's assertive attempts to deepen bilateral integration ever since late 2018. This explains the position of Belarus's leadership, which, in the context of Brexit, has expressed its interest in a strong EU, 'maybe as no one else has done' (Lukashenka, 2019, SI 6.1). The EU-Belarus positive othering has thus been supporting a 'free and independent' Belarus (Lukashenka, 2009, SI 6.15) and has emerged as an important factor in the ability of Belarus to maintain a necessary distance from Russia, regardless of the latter being continuously identified as Belarus's significant we.

\section{Conclusions}

This article has argued that the diversity underpinning the $\mathrm{EaP}$ is a result of the positioning of individual EaP states' towards a dimension of the EU's self, the EU's potential we. Attachment to the latter has varied according to the different constellations of EaP state identities and assumed different institutional expressions. Having used three ideal types to guide this framing analysis, a (re)categorization of the positioning of EaP states can now be presented (see Table 3), serving as a basis for the conclusions to be drawn from this study.

First, the positioning of Ukraine, Georgia, and Moldova is associated with the first ideal type, comprising the category of 'accepting the EU's potential we', supported by 
the civilizational choice framing that constitutes these EaP states' identities. A decade after the inception of the EaP and despite its existential challenges, it can thus be confirmed that the EU acts as others' significant we and as a source of legitimacy for the EaP states associated with defining the 'appropriate' course of action' (Casier, 2011; also see Noutcheva, 2017).

Azerbaijan fits the third ideal type. While rejecting both the EU and Russia's significant we, Azerbaijan has explicitly and actively contested the EU's potential we by projecting its own reversed altercasting towards the EU, asserting this in terms of selfother interaction and demonstrating a preference for a strategic partnership agreement.

At first glance, Armenia and Belarus could be labelled as the second ideal type due to their recognition of Russia as their significant we. However, Armenia's special attachment to the EU's potential we (via CEPA, but also via domestic developments since 2018) places it in its own category; 'holding to the EU's potential we', with the associated theme of choosing the EU's potential we but not at the expense of Russia. In this regard, Armenia's CEPA, while creating a new model of advanced cooperation with the EU and setting a precedent for other EAEU countries, also implies a more distant and diluted attachment to the EU's potential we that acknowledges Russia's interference in EaP states' altercasting with the EU. Thus, this analysis points to a potentially problematic relationship between complementarity and (ir)reversibility in terms of acceptance of the EU's potential we. The fate of the CEPA, either as a positive precedent guiding and supporting the reform process of $\mathrm{EaP}$ (and non-EaP) countries, or a dangerous example causing a reverse process, including a possible detachment or abandoning of the AA/DCFTA, will eventually depend on the existence of a 'collective we' shared between Russia, the EU, and EaP states. The latter cannot be taken for granted and therefore remains the main challenge to any ideas to connect the EAEU and EaP states institutionally.

While Russia continues to feature as Belarus's significant we, the EU is increasingly seen as an actor supporting Belarusian independence and sovereignty. Thus, Belarus's contestation of the EU's potential we is different from Azerbaijan's: while contesting the essence of the EU's potential we, Belarus has been careful to avoid compromising positive othering altercasting with the EU, which is reflected in their pragmatic framing. Belarus has thus not insisted on a special cooperation agreement or format, whether within the EaP or beyond. Belarus's framing and associated altercasting resonates with the EU's recent emphasis on pragmatism and resilience, while also highlighting a challenge for the EU; namely to reconcile the acceptance of states with a status quo orientation, like Belarus, with the EU aspiration to promote potentially disruptive change (Joseph and Juncos, 2019, p. 1,002; see Bosse, 2009).

Two additional conclusions can be drawn from this analysis. First, as a recent dimension of the EU's self, the EU's potential we still tends to be associated with another, superordinate EU identity. When the potential we is contested, this contestation is associated with the EU's identity as the socializer and promoter of political conditionality. Similarly, when AA/DCFTA countries accept the EU's potential we, they derive the legitimacy for their effort to promote EU-oriented reforms or democratization from the prospect of a close association with the EU's self (EU's prospective we'), reflected in their respective reversed altercasting. Ukraine and Georgia have been thus reaching beyond the AA/DCFTA, challenging it as an identitarian reference point and an unsuitable fit for their prospective we aspirations. Ideas like 'four unions with the EU' (Ukraine) or ad hoc 
accession negotiations (Georgia) confirm the EU's tendency towards 'rhetorical entrapment' (Casier, 2011) in its relations with EaP states and demonstrate a need for further research to identify the principles and mechanisms underpinning the projection of the EU's potential we and its influence on the transformation of these countries (Delcour, 2019), including possible non-enlargement incentives for DCFTA states. More generally, the demonstrated different ways in which the EaP states have dealt with the EU's potential we point to a need for a more fine-grained (framing) analysis of the six states' positions beyond the division of the EaP countries into DCFTA/non-DCFTA states.

Second, while the acceptance of the EU's potential we is not always associated with a negative othering of Russia, the fact that it is more straightforward to classify EaP states as belonging to the first rather than the second ideal type attests to the relative success of the EU's projection of its identity on its neighbourhood, compared with Russia's projection of its significant we. This seems to be correlated with a more pronounced (negative) reversed altercasting/othering of Russia, as compared with the (positive) reversed altercasting towards the EU. This finding allows the present research to be connected to the debate on the attraction of Russia's 'soft power' in its 'near abroad' and the associated dynamics of EAEU integration (Busygina, 2017), while also confirming that the EU-EaP space of interaction will remain a site of contestation in the future.

Correspondence:

Alena Vieira

Department of Political Science

School of Economics and Management

University of Minho, Campus of Gualtar

4710-057 Braga

Portugal

email: d4215@eeg.uminho.pt

\section{References}

Adler-Nissen, R. (2016) 'The Social Self in International Relations: Identity, Power and Symbolic Interactionist Roots of Constructivism'. European Review of International Studies, Vol. 3, No. 3 , pp. 27-39.

AGERPRES (2019) 'Russian Propaganda, Real and Serious Problem for Moldova, Says Maia Sandu.' 29 September. Available online at: https://www.agerpres.ro/english/2018/09/29/ russian-propaganda-real-and-serious-problem-for-r-moldova-says-maia-sandu-184401 . Accessed 1 February 2020.

Baltag, D. and Bosse, G. (2016) 'The EU's Eastern Partnership with Moldova: A 'Best-Case' Scenario for EU Security Community-Building?' In Rieker, P. (ed.) External Governance as Security Community Building. The European Union in International Affairs (London: Palgrave Macmillan), pp. 49-77.

Belta (2017). 'Belarus does not plan to join EU, but shows interest in Eastern Partnership'. 11 December. Available online at: https://www.belta.by/special/politics/view/belarus-neplaniruet-stanovitsja-chlenom-es-no-zainteresovana-v-vostochnom-partnerstve-kravchenko279848-2017/. Last accessed 1 February 2020. 
Bosse, G. (2009) 'Challenges for EU Governance through Neighbourhood Policy and Eastern Partnership: the Values/Security Nexus in EU-Belarus Relations'. Contemporary Politics, Vol. 15, No. 2, pp. 215-27.

Bosse, G. (2010) 'The EU's Relations with Moldova: Governance, Partnership or Ignorance'. Europe-Asia Studies, Vol. 62, No. 8, pp. 1291-309.

Busygina, I. (2017) Russia-EU Relations and the Common Neighborhood: Coercion vs Authority (London and New York: Routledge).

Casier, T. (2011) 'To Adopt or Not to Adopt: Explaining Selective Rule Transfer under the European Neighbourhood Policy'. Journal of European Integration, Vol. 33, No. 1, pp. 37-53.

civil.ge (2013) 'Saakashvili: PM's Eurasian Union Remarks "Break Main Taboo" of Georgian Politics’. 12 September. Available online at: https://civil.ge/archives/186782. Last accessed 1 February 2020.

Constitutional Law of Georgia (2017). No 1324 of 13.10.2017. Available online at: https://matsne. gov.ge/en/document/view/30346? publication=35. Last accessed 1 February 2020.

De Vreese, C.H. and Boomgaarden, H.G. (2003) 'Valenced News Frames and Public Support for the EU'. Communications, Vol. 28, No. 4, pp. 361-81.

Delcour, L. (2019) 'Armenia's and Georgia's Contrasted Positioning vis-à-vis the EU: Between Vocal Centrality and Strategic Marginality'. Journal of Contemporary European Studies, Vol. 27, No. 4, pp. 439-50.

Delcour, L. and Wolczuk, K. (2015) 'The EU's Unexpected "Ideal Neighbour”? The Perplexing Case of Armenia's Europeanisation'. Journal of European Integration, Vol. 37, No. 4, pp. 491-507.

Entman, R.M. (1993) 'Framing: Toward Clarification of a Fractured Paradigm'. Journal of Communication, Vol. 43, No. 4, pp. 51-8.

EU-Azerbaijan Cooperation Council (2006). EU-Azerbaijan Action Plan, Brussels, 14 November. Available online at: https://eeas.europa.eu/sites/eeas/files/au-az_action_plan azerbaijan.pdf. Last accessed 1 February 2020.

Euractiv (2019) 'Georgia Suggests Taking an Unconventional Path to EU Accession'. 11 July. Available online at: https://www.euractiv.com/section/eastern-europe/news/georgia-suggesttaking-an-unconventional-path-to-eu-accession/. Last accessed 1 February 2020.

European Commission (2003) Wider Europe - Neighbourhood: a New Framework for Relations with our Eastern and Southern Neighbours, Brussels, 11 March. Available online at: http:// eeas.europa.eu/archives/docs/enp/pdf/pdf/com03_104_en.pdf. Last accessed 1 February 2020.

Flockhart, T. (2011) 'NATO and the (Re)construction of Roles: "Self", "We", and "Other"?' In Harnisch, S., Frank, C. and Maull, H. (eds) Role Theory in International Relations: Approaches and Analyses (Abingdon: Routledge), pp. 95-112.

Gamson, W.A. and Modigliani, A. (1989) 'Media Discourse and Public Opinion on Nuclear Power: A Constructionist Approach'. American Journal of Sociology, Vol. 95, No. 1, pp. 1-37.

Ghazaryan, N. (2014) 'Legislative Approximation and Application of EU Law in Azerbaijan'. In Petrov, R. and van Elsuwege, P. (eds) Legislative Approximation and Application of EU Law in the Eastern Neighbourhood of the European Union (London and New York: Routledge), pp. $215-27$.

van Gils, E. (2018) 'Azerbaijan's Foreign Policy Strategies and the European Union: Successful Resistance and Pursued Influence'. Europe-Asia Studies, Vol. 70, No. 5, pp. 738-58.

van Hulst, M. and Yanow, D. (2016) 'From Policy "Frames" to "Framing": Theorizing a More Dynamic, Political Approach'. American Review of Public Administration, Vol. 46, No. 1, pp. 92-112.

Joseph, J. and Juncos, A. (2019) 'Resilience as an Emergent European Project? The EU's Place in the Resilience Turn'. JCMS, Vol. 57, No. 5, pp. 995-1012. 
Kropatcheva, E. (2016) 'The EU's Policy of Democracy Promotion and Ukraine's Bumpy Path to the Association Agreement - Amidst a Major Crisis in Europe'. In Axyonova, V. (ed.) European Engagement under Review (Stuttgart: Ibidem), pp. 11-40.

Law of Ukraine. On the Introduction of Amendment of the Constitution of Ukraine 2680-VII, of 07.02. 2019. Available online at: https://zakon.rada.gov.ua/laws/show/2680-19. Last accessed 1 February 2020.

Malici, A. and Walker, S. (2014) 'Role Theory and 'Rogue States'. In Wagner, W. (ed.) Deviance in International Relations: 'Rogue States' and International Security (Basingstoke: Palgrave), pp. $132-51$.

Mead, G. (1934) Mind, Self, and Society (Chicago, IL: University of Chicago Press).

Ministry for Foreign Affairs of Armenia (2019). 'The Meeting of Foreign Minister Mnatsakanyan at the French Institute of International Relations, 17 April'. Available at: https://www.mfa.am/ en/press-releases/2019/04/17/fm_ifri/9408. Last accessed 1 February 2020.

Moldavskie Vedomosti (2013). 'Филат не хочет, чтобы Молдова оставалась "Золушкой” для EC'. (Filat does not want Moldova to continue as EU's Cinderella) Available at: http://www.vedomosti.md/news/Filat_Ne_Hochet_Chtoby_Moldova_Ostavalas_ Zolushkoi_Dlya_Es. Last accessed 1 February 2020.

Moldavskie Vedomosti (2016). 'Додон: Подписав Соглашение об ассоциации с ЕС, Молдова пошла на добровольное самоубийство’. (By signing the Association Agreement with the EU, Moldova committed voluntary suicide) Available online at: http:// www.vedomosti.md/news/dodon-podpisav-soglashenie-ob-associacii-s-es-moldova-poshla. Last accessed 1 February 2020.

Mols, F. and Webber, M. (2013) 'Laying Sound Foundations for Social Identity Theory-inspired European Union Attitude Research: Beyond Attachment and Deeply Rooted Identities'. JCMS, Vol. 51, No. 3, pp. 505-21.

Noutcheva, G. (2017) 'Whose Legitimacy? The EU and Russia in Contest for the Eastern Neighbourhood'. Democratization, Vol. 25, No. 2, pp. 312-30.

Oskanian, K. (2013) Fear, Weakness and Power in the Post-Soviet South Caucasus: A Theoretical and Empirical Analysis (Basingstoke: Palgrave Macmillan).

Prodi, R. (2002) 'A Wider Europe - A Proximity Policy as the Key to Stability'. Available online at: http://europa.eu/rapid/press-release_SPEECH-02-619_en.htm. Last accessed 1 February 2020.

Raik, K. (2017) 'The Ukraine Crisis as a Conflict over Europe's Political, Economic, and Security Order'. Geopolitics, Vol. 24, No. 1, pp. 51-70.

Rein, M. and Schön, D. (1993) 'Reframing Policy Discourse'. In Fischer, F. and Forester, J. (eds) The Argumentative Turn in Policy Analysis and Planning (London: UCL).

Samokhvalov, V. (2017) Russian-European Relations in the Balkans and Black Sea Region: Great Power Identity and the Idea of Europe (Basingstoke: Palgrave Macmillan).

Schmidt-Felzmann, A. (2016) 'The Breakdown of the EU's Strategic Partnership with Russia: From Strategic Patience towards a Strategic Failure'. Cambridge Review of International Affairs, Vol. 29, No. 1, pp. 99-127.

Smith, J. and Richardson, P. (2017) 'The Myth of Eurasia - a Mess of Regions'. Journal of Borderlands Studies, Vol. 32, No. 1, pp. 1-6.

Tajfel, H. and Turner, J.C. (1986) 'The Social Identity Theory of Intergroup Behaviour'. In Worchel, S. and Austin, W. (eds) Psychology of Intergroup Relations (Chicago, IL: Nelson Hall), pp. 7-24.

UNIAN (2019) 'MFA Ukraine Reacts to Slovenian President's Statements about Ukraine's "Special Status" in EU'. Available online at: https://www.unian.info/politics/10674168-mfaukraine-reacts-to-slovenian-president-s-statements-about-ukraine-s-special-status-in-eu.html. Last accessed 1 February 2020. 
Vasilyan, S. (2016) 'Swinging on the Pendulum: Armenia in the Eurasian Economic Union and with the European Union'. Problems of Post-Communism, Vol. 64, No. 1, pp. 32-46.

Verpoest, L. (2007) 'Parallels and Divergences of Integration in Ukraine and Belarus'. In Malfliet, K., Verspoest, L. and Vinokurov, E. (eds) The CIS, the EU and Russia (Basingstoke: Palgrave Macmillan), pp. 145-70.

Vieira, A. (2016) 'Ukraine, Russia and the Strategic Partnership Dynamics in the EU's Eastern Neighbourhood: Recalibrating the EU's 'Self', 'We' and 'Other'. Cambridge Review of International Affairs, Vol. 29, No. 1, pp. 128-50.

Waever, O. (1998) 'Insecurity, Security, and Asecurity in the West European Non-War Community’. In Adler, E. and Barnett, M. (eds) Security Communities (Cambridge: Cambridge University Press), pp. 69-118.

Weber, M. (1949) The Methodology of the Social Sciences (Glencoe, IL: Free Press).

Wendt, A. (1999) Social Theory of International Politics (Oxford: Oxford University Press).

Whitman, R. and Wolff, S. (2010) The European Neighbourhood Policy in Perspective: Context, Implementation, and Impact (Basingstoke: Palgrave Macmillan).

\section{Supporting Information}

Additional supporting information may be found online in the Supporting Information section at the end of the article.

Annex S1. Detailed references to all mentioned statements of Presidents and Prime Ministers as well as key strategic documents are listed in the document published in the online version of the article. 